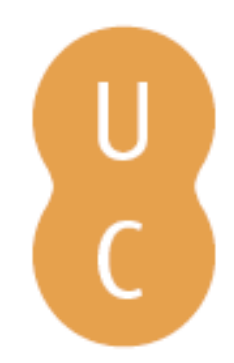

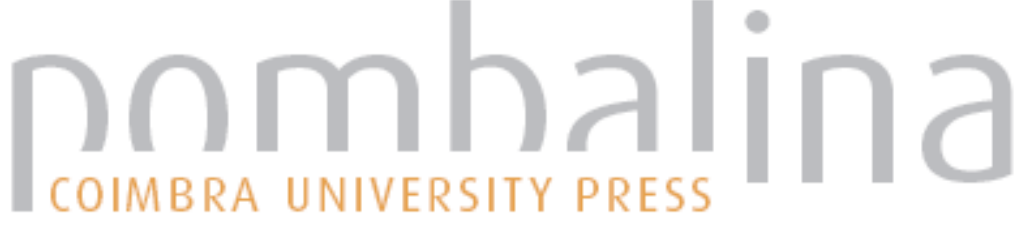

\section{Valores culminantes: educação para a morte/educação para a vida}

\author{
Autor(es): $\quad$ Azevedo, Maria da Conceição \\ Publicado por: Imprensa da Universidade de Coimbra \\ URL \\ persistente: URI:http://hdl.handle.net/10316.2/38393 \\ DOI: $\quad$ DOI:http://dx.doi.org/10.14195/978-989-26-0486-2_15 \\ Accessed : $\quad$ 26-Apr-2023 13:40:16
}

A navegação consulta e descarregamento dos títulos inseridos nas Bibliotecas Digitais UC Digitalis, UC Pombalina e UC Impactum, pressupõem a aceitação plena e sem reservas dos Termos e Condições de Uso destas Bibliotecas Digitais, disponíveis em https://digitalis.uc.pt/pt-pt/termos.

Conforme exposto nos referidos Termos e Condições de Uso, o descarregamento de títulos de acesso restrito requer uma licença válida de autorização devendo o utilizador aceder ao(s) documento(s) a partir de um endereço de IP da instituição detentora da supramencionada licença.

Ao utilizador é apenas permitido o descarregamento para uso pessoal, pelo que o emprego do(s) título(s) descarregado(s) para outro fim, designadamente comercial, carece de autorização do respetivo autor ou editor da obra.

Na medida em que todas as obras da UC Digitalis se encontram protegidas pelo Código do Direito de Autor e Direitos Conexos e demais legislação aplicável, toda a cópia, parcial ou total, deste documento, nos casos em que é legalmente admitida, deverá conter ou fazer-se acompanhar por este aviso.

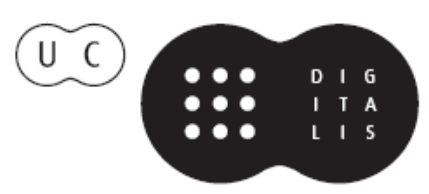


João Boavida

Ángel García del Dujo

Coordenação

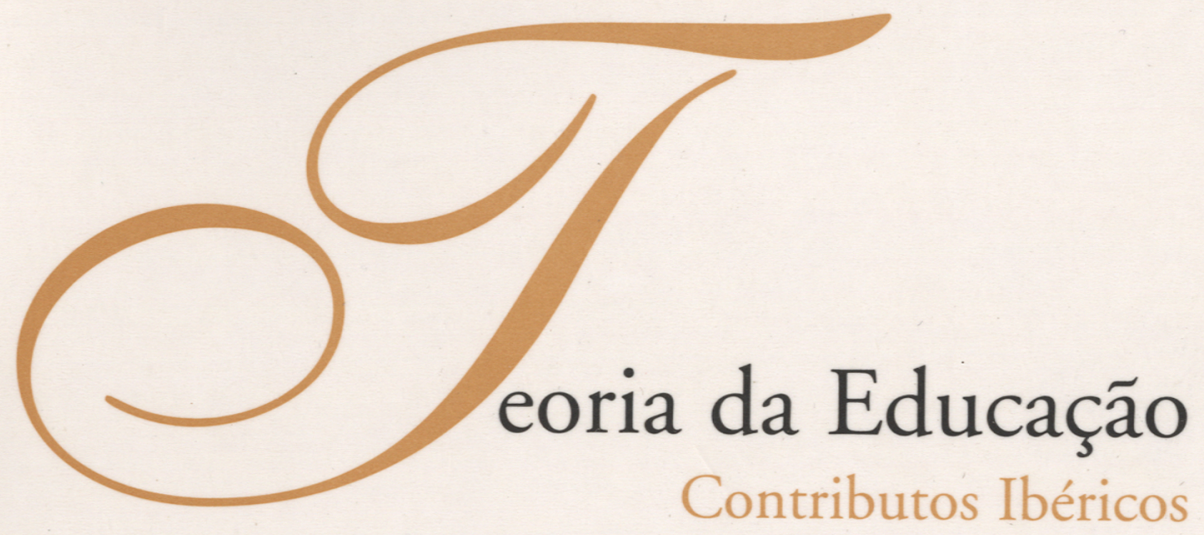


M aria da Conceição Azevedo

Universidade de Trás-os-Montes e Alto-Douro

Val or es cul minant es:

EDUCAÇÃO PARA A M ORTE/EDUCAÇÃO PARA A VIDA

Porquê e para quê educar, se o mundo estiola e apodrece?

Ou o mundo estiola e apodrece porque falta educar?

A história da pedagogia —a história da humanidade —é feita do elenco de respostas a esta questão de duas faces. Por aí passa toda a transmissão do saber, todo 0 esforço da ciência e da técnica. Aí se enquadram todos os progressos da civilização e todas as procuras da espiritualidade.

Mas esta é sobretudo a questão a que não pode fugir nenhum educador. Ele é uma pessoa como as outras... Mas enquanto educador, é uma pessoa que trabalha com pessoas. Do seu agir ou aparente apagar-se, do seu querer conduzir ou contentar-se com alimentar os outros, adultos ou crianças, virão consequências que precipitarão 0 mundo ou 0 farão saltar «como bola colorida». Por isso, como Paulo Freire (1997: 122) sublinha, «a educação é uma acto de intervenção no mundo», tanto se esta intervenção «aspira a mudanças radicais na sociedade», como se «pretende imobilizar a História e manter a ordem injusta».

Se pensamos nos educadores profissionais, poderemos dizer que a escolha por um ou por outro sentido da sua acção não é dado do seu diploma, nem elemento da sua classificação profissional E, todavia, é aí que se exerce a mais profunda responsabilidade do educador. A escolha por um ou outro sentido (melhor, a escolha pelo sentido ou a desistência perante 
0 nâo-sentido) do educar não se faz de um momento para 0 outro, nem se propaga automaticamente no labor de cada dia. Ela é 0 fruto de um regressar constante e de urna cada vez mais profunda resposta à pergunta que atrás colocámos: Porquê e para qué educar, se 0 mundo estiola e apodrece? Ou 0 mundo estiola e apodrece porque falta educar?

E se esta questão se tornar de verdade 0 ponto chave do seu ser, então 0 educador será a voz que clama no deserto e obriga quantos encontrar a perguntarem-se: Porqué e para quê viver se 0 mundo estiola e apodrece? Ou o mundo estiola e apodrece porque falta viver?

0 texto que se segue pretende, no contexto da teoria da educação, abordar a problemática dos valores (sua hierarquização, sua criação e promoção), partindo destas duas questões: Porquê e para quê educar? Porquê e para quê viver?

\section{A problemática dos valores culminantes e sua relação com a teoria da educação}

Fullat (1991: 443) define Teoria da Educação como a «teoria explicativa e global dos processos educativos na medida em que estes são aprendizagem de informações, de atitudes e de habilidades».

Em obra com esse mesmo título, Carrasco e Dujo (1996:19) propõem que 0 trabalho desta disciplina é indissociável das questões com que se encontram os profissionais da educação, tanto enquanto espaço de acção como enquanto campo de conhecimento. Apresentam três definições de Teoria da Educação de complexidade progressiva, às quais nos referiremos no decurso deste trabalho:

a) estrutura simbólica com a qual os homens habitualmente tomam decisões educacionais (adiante referida como TE 1);

b) representação intelectual com que os profissionais da educação interpretam situações pedagógicas específicas (TE 2); 
c)organização de conceitos educacionais construída mediante a aplicação de critérios e regras da epistemologia (TE 3). (Carrasco e Dujo, 1996: 25).

Como os mesmos autores apontam adiante (p. 26), analisa-se no primeiro caso a tradição pedagógica da cultura; no segundo, as teorias pessoais dos agentes educativos e, no terceiro, procura construir-se ciência da educação.

Em qualquer uma das acepções está, porém, presente 0 problema dos valores, da sua hierarquia e sentido. Com efeito, os procedimentos intuitivos identificados na tradição cultural, a prática educativa (profissional ou não) e 0 trabalho do investigador revelam e veiculam uma opção axiológica. Podemos, por isso, dizer que todas as pedagogias (intuitivas, profissionais e teóricas) são pedagogias do valor e implicam uma reflexão sobre os valores efectivamente promovidos, a sua hieraruização e justificação teórica. Com efeito, subjacente ao acto educativo, embora nem sempre formulada, está a pergunta: vale a pena educar? Por detrás de todas as suas divergências, perfila-se uma resposta unânime de todas as pedagogias: vale a pena educar se alguma coisa vale $e$ apenas para aquilo que vale. Se nada vale e tudo é indiferente, não só é irrelevante 0 que se ensina, mas sobretudo é irrelevante 0 porquê viver, gerar e educar. Mais: educar, gerar e viver tornam-se constelações de actos completamente destituídos de sentido, do mesmo modo que a sua suspensão. 0 valor —que subjaz a toda a acção humana(1) —atravessa por maioria de razão todo 0 trabalho educativo. Na verdade, a educação não pode ser uma aventura fortuita, antes exige uma análise crítica de normas e projectos e uma garantia de compreensão e fidelidade àqueles que vierem a merecer acolhimento.

(1) Recorrendo à parábola evangélica do mercador de pérolas, Réboul explica que 0 valor, na sua relação com 0 sujeito, envolve uma tríplice dimensão: adesão afectiva, juízo racional e acção coerente. 0 sujeito encontra-se com 0 valor mediante um conhecimento imediato, intuitivo e emocional; contudo, esta operação afectiva, emocional, é «penetrada por elementos cognitiv0s» (a intencionalidade da consciência). Sem ela, os valores reduzir-se-iam à escolha caprichosa e efémera dos indivíduos, assim como, sem 0 elemento emocional, não seriam mais que 0 conhecimento frio de finalidades. Mas só podemos verdadeiramente falar de valor quando, em resultado desta síntese se processa na vida do sujeito uma acção coerente. Os valores não 0 são realmente se não são persistentes na vida da pessoa, se a não enformam e impulsionam. (Cf. Réboul, 1992: 29-37). 
Mas darmos uma resposta afirmativa à pergunta sobre 0 valor do educar não resolve tudo. Permanecem muitas interrogações: Que valores merecem a designação de culminantes? Porquê? Qual o critério que os define? São os mesmos para todos? Dentro dessa ordem de valores há ainda uma sub-hierarquia? Os valores culminantes podem ensinar-se? Como se aprendem? Quem são os seus mestres? Que qualidades se exigem destes?

Por outro lado, todas estas questões têm uma dimensão prática irrenunciável, para além e acima das respostas teóricas que recebem. A vida não se confina às margens das teorias. Anula sempre a sua falsidade ou estreiteza. A vida é acção. E agir é escolher: mover-se ou ficar parado, calar-se ou falar, deixar-se morrer ou querer viver. Ora escolher envolve tanto o processo de discernimento como a realização, os quais são indissociáveis um do outro. A escolha se, por um lado, é a própria objectivação do acto de valorar já que se escolhe 0 que se valoriza, permite também, tanto pelo processo de discernimento como pela subsequente análise das consequências, uma reapreciação da anterior escala de valores. Por essa razão, as questões agora propostas não são apenas questões da filosofia dos valores, mas também questões relevantes no âmbito da Teoria da Educação. Não há, efectivamente, actos neutros, nem nas pequenas escolhas do dia-a-dia, muito menos quando estão em causa as escolhas fundamentais da existência, aquelas a que associamos 0 «sentido da vida», a descobrir ao longo do percurso educativo. Nestas se revelam os valores colocados em lugar supremo pelo indivíduo, cuja concretização the proporciona sentimentos de plena realização e the permite a superação das dificuldades internas e externas, a par de uma progressiva consciência, tanto da sua identidade como da natureza dos laços que 0 ligam aos outros.

Aos valores que determinam estas escolhas fundamentais da existência e são condição de possibilidade e de realização de todos os outros valores chamamos culminantes. Encontramos neles as seguintes características:

- totalidade, isto é, estes valores possibilitam a integração de cada juízo axiológico e de cada escolha concreta na unidade da vida do sujeito e mesmo da comunidade humana na qual ele se integra; 
- ultimidade, ou seja, apresentam-se ao sujeito como horizonte do seu agir e da sua realização pessoal, implicam um constante dinamismo, na medida em que nenhum juízo ou acção concreta os esgota;

- inteligibilidade, quer dizer, enquanto realidade vivida são susceptíveis de tradução num juízo axiológico dotado de sentido, isto é, não absurdo, não arbitrário, não contraditório com as respectivas consequências.

A relevância destas questões torna-se evidente no trabalho educativo: se é certo que nenhum educador tem 0 direito de fornecer aos seus educandos um projecto de vida já pronto, não pode todavia eximir-se à tarefa de discussão e análise dos valores que suportem 0 projecto de cada um. Daí a urgência de as colocar à luz da Teoria da Educação a fim de:

a) identificar 0 sentido das decisões educacionais num dado contexto cultural (cf. TE 1);

b) clarificar a coerência axiológica interna das situações intencionalmente pedagógicas (cf. TE 2);

c) construir os fundamentos de uma pedagogia do discernimento que permita a autodeterminação do educando e a coerência do educador (cf. TE 3).

Estes três aspectos interpenetram-se, uma vez que 0 último não ocorre desencarnado da prática da educação nem fora de respectivo contexto cultural. Por outro lado, a possibilidade de erro, presente em toda a actividade humana - e ocasionalmente invocada como critério de cientificidade -assume, neste contexto, o carácter dramático das escolhas irreversíveis como irreversível é a própria vida, condição e consequência de toda a escolha e discernimento. 


\section{Divergências de posições e critérios para a definição de valores culminantes}

Não foi possível até hoje —não parece possível em absoluto —estabelecer uma escala axiológica que merecesse 0 acordo de todos os filósofos nem de todos os pedagogos, uma vez que a posição assumida neste contexto se articula directamente com a posição metafísica do autor/educador em causa, seja ele consciente dela ou não.

Como sublinha Quintana Cabanas (1998: 165), o exemplo dos valores morais é notável. Enquanto uns, como Scheler e Hessen, os subordinam aos valores religiosos, outros, como Kant e Natorp, erigem a moral como valor supremo e reduzem a religião a mera pedagogia moral cuja única tarefa seria conduzir os homens à prática do bem. 0 confronto dos valores morais com os valores estéticos redunda em nova controvérsia: uns, seguindo a Sócrates e Platão, consideram que a estética há-de subordinar-se à moral; outros, como Kierkegaard, Baudelaire, Salman Rushdie,... consideram que a arte se sobrepõe à moral; por seu lado, Nietzsche defenderá que só a arte pode reconciliar o homem com a existência, negando todos os valores éticos e religiosos da tradição anterior, ao passo que, por exemplo, Plotino e Tolstoi entendem que toda a arte é religiosa.

Alguns autores pretenderam também justificar a escala axiológica que propõem, havendo mesmo quem defenda que «numa escala de valores bem feita, cada valor ocupa um lugar preciso em relação com 0 que 0 precede e 0 que 0 segue, porque todo 0 valor é, ao mesmo tempo, condição do primeiro e condicionante do segundo» (Quintana Cabanas, 1998: 164).

Nesta linha, propomos alguns exemplos:

Max Scheler (1874-1928) refere cinco critérios: duração (os valores são tanto mais elevados quanto mais duradouros); divisibilidade (os valores são tanto mais elevados quanto mais se prestam a ser possuídos em comum e de maneira indivisa); satisfação (os valores são tanto mais elevados quanto mais profunda é a satisfação que provocam); fundamentação (os valores 
fundamentantes são superiores aos fundamentados); relatividade (um valor é tanto mais relativo quanto mais longínqua for a sua relação com os valores independentes ou absolutos). Concordante com estes critérios é a escala axiológica que propõe (por ordem crescente): valores do prazer; valores vitais; valores espirituais; valores do santo e do profano (Patrício, 1993: 253-4).

Wilhelm Stern (1871-1938) estabelece os seguintes critérios para fundamentar a sua hierarquia axiológica: plenitude, proximidade, urgência e ressonância dos valores, relativamente ao sujeito.(Quintana Cabanas, 1998: 163). Em coerência com estes critérios, dá a primazia aos valores próprios (ou de pessoas') que se subdividem em valores «centrais» e «excêntricos», conforme a sua proximidade do eu e a ressonância quanto à vocação do sujeito; e subordina-lhes os valores derivados (ou de coisas), os quais podem ser de quatro tipos, a saber, irradiados, de serviço, de domínio, de troca (Quintana Cabanas, 1998: 152).

Lavelle (1883-1951) considera que a hierarquia dos valores se funda na relação destes com 0 tempo, o desejo e 0 esforço que exigem do sujeito, embora afirme também que é sempre 0 valor supremo que se expande nos valores particulares. Considerando que o ser humano se situa no mundo, pode distinguir-se dele e mesmo transcendê-lo, Lavelle estabelece três ordens de valores (por ordem crescente):valores de pertença ao mundo (económicos e afectivos), valores de contemplação do mundo (intelectuais e estéticos) e valores para transcender 0 mundo (morais e religiosos).

Os critérios definidos permitem, dentro do sistema de cada autor, justificar 0 carácter subordinado ou subordinante dos diversos valores. Porém, uma análise mais fina mostra que a hierarquização axiológica decorre últimamente da posição metafísica assumida pelo autor em causa. Se este é racionalista ou espiritualista (como os que apontámos), considerará superiores os valores ideais e inferiores os valores materiais ou sensíveis. Pelo contrário, se for materialista, colocar-se-á na posição exactamente inversa. Assim, Herbert Spencer, coloca no topo da sua escala a actividade que concorre 
directamente para a conservação do individuo, tal como o marxismo faz relativamente ao trabalho e David Hume com a utilidade para a comunidade.

Os criterios fundamentadores de uma hierarquização axiológica revelam-se-nos, portanto, mais como justificação a posteriori do que como axioma e ponto de partida.

Savater (1982: 63-4) afirma, por isso, num aparente subjectivismo:

«0 que não vale é 0 que não nos vale [...] 0 que vale para 0 homem não é senão 0 que ele quer; [...] 0 que ele quer é, em primeiro lugar, ser; em segundo lugar, ser mais, iluminar-se, ampliar-se e reafirmar-se no ser; em terceiro lugar (ou em terceiro nível) ser uma totalidade não-idêntica, aberta ao possível e autodeterminada. A origem de todos os valores está nestes níveis do querer humano e aqui reside a sua objectividade e a sua idealidade.»

Por seu lado, Réboul analisa demoradamente a natureza do juízo ou discernimento axiológico fazendo notar que:

- A palavra discernimento designa tanto 0 acto como a competência de 0 produzir;

- 0 acto de discernir envolve um conteúdo e uma decisão, portanto, um factor de realidade e um factor de liberdade;

- 0 acto de discernir pode assumir uma função crítica (exame da realidade presente) e uma função criativa (progressão do conhecido e aceite para 0 desconhecido e o novo) e tem sempre uma dimensão moral.

Assim, 0 juízo axiológico - a que os autores antigos chamaram discernimento ou prudência (a phronesis') — distingue-se, na tradição aristotélica, da sabedoria (contemplação das verdades eternas) e da ciência (conhecimento do que é susceptível de produzir-se reduzindo-o a uma lei abstracta). Pelas limitações do conhecimento e da liberdade do sujeito, é sempre susceptível de erro, mas compromete 0 mesmo sujeito com 0 
seu conteúdo, qualquer que ele seja: sabendo que posso enganar-me na concretização da minha escala axiológica, nada me dispensa do esforço de procurar evitar 0 erro para todos os meios (Réboul, 1992: 174-6). De onde a urgência de uma pedagogia do discernimento a que fizemos referência no ponto anterior.

0 problema que colocámos — Que valores merecem a designação de culminantes? —-parece exigir uma abordagem diferente. Busquemos, pois, uma outra perspectiva de onde olhar o nosso problema.

\section{A morte - ponto de partida existencial para a análise do problema dos valores culminantes}

Existencialmente verificamos que é a finitude (atingindo cada um de forma irremediavelmente pessoal) que confere à hierarquização axiológica concretizada em cada acção o dramatismo de poder ser a última e definitiva escolha.

A consciência da morte —que necessária e iniludível nos espreita —abala a pessoa até ao núcleo do seu ser. A morte repentina de alguém que nos é próximo ou de uma figura pública e, mais que todas, a morte de uma criança ou de um jovem põem-nos perante 0 mistério da morte, 0 enigma da vida.

Os poetas exprimem-no da forma mais perfeita. Rilke exclama: «Ó Senhor, dá a cada um a sua própria morte» (Apud Fagot-Largeault, 2001: 1681) e, na nossa língua, poucos o terão feito como Pessoa que nos deixou muitos poemas em que a angústia e mesmo 0 terror da morte nos obrigam a confrontarmo-nos com a sua constante ameaça e com 0 mistério do existir. Em 0 Menino de sua Mãe di-lo na terceira pessoa: a morte no absurdo da violência e da guerra. Mas será em Álvaro de Campos e no Fausto que ela surge como a vertigem metafísica do nada, ou, o que é mais, a consciência do mistério, a intuição dramática de que ela é a brecha por onde (se) espreita 0 infinito: 
Gela-me a ideia de que a morte seja

0 encontrar 0 mistério face a face

E conhecê-lo. Por mais mal que seja

A vida e 0 mistério de a viver

E a ignorancia em que a alma vive a vida,

Pior me relampeja pela alma

A ideia de que enfim tudo será

Sabido e claro - e este mistério imenso,

Que não entendo já, do que é grande

Por não ser sabido e adivinhado,

Me pesa n'alma, venha a ser sabido

$E$ a realidade em todo 0 seu horror

Desabe sobre a minha consciência

Condenada ao horror de ser consciente.

Pudesse eu ter por certo que na morte

Me acabaría, me faria nada

E eu avançara para a morte, pávido,

Mas firme do seu nada. (Pessoa, 1988: 59-60)

Em clara oposição à lucidez do poeta que encara, ainda que com horror, 0 mistério da morte, encontramo-nos hoje com duas atitudes que parecem opor-se: ou se converte a morte em tabú, procurando escondê-la por todos os meios; ou se faz déla espectáculo de televisão ou elemento de jogo virtual, figurando como condimento excitante que se contrapõe ao fastio generalizado da vida. No Prefácio ao livro de Marie de Hennezel (2002: 7) La mort intime, escreve François Mitterrand:

Talvez qne nunca a relação com a morte tenha sido tão pobre como nestes tempos de aridez espiritual em que os homens, na pressa de existir; parecem sofismar o mistério. Ignoram que, desse modo, secam uma fonte essencial do gosto de viver. 
De um lado, a marginalização: esconde-se 0 cadáver, reduzem-se ao mínimo os rituais da sepultura e do luto, considera-se anormal a tristeza dos familiares e amigos e recomenda-se-lhes um médico que thes receite anti-depressivos. Mas a marginalização começa muito antes, com certa «conspiração de silêncio» que rodeia 0 moribundo e que, a pretexto de 0 proteger, lhe nega 0 direito de «olhar a morte de frente e continuar a viver, dando sentido à vida» (Hennezel, 2002: 19). Não raro também, a morte iminente de doentes em situação terminal é sentida pelos profissionais de saúde como um fracasso: ministram sedativos, evitam 0 doente e a família... Por outro lado, pela extraordinária frequência com que lidam com a morte, pelo conhecimento técnico dos processos que a ela conduzem, por efeito da distanciação terapêutica necessária à sua própria sobrevivência, os mesmos profissionais correm 0 risco de não reconhecer a morte humana por detrás de um coração que pára, de um tumor que invade um cérebro, de uma hemorragia que nada pôde estancar: banalizam-na, o que os impede de comunicar com o doente ou com os seus familiares. Podem falar-hes, dar pormenores sobre 0 estado clínico do doente, mas fazem-no com maior indiferença que um pivot de televisão que apresenta 0 telejornal. Ora, negando a comunicação, instalam realmente a morte entre si e os outros, mas tornam-se incapazes de a compreender, o que é outra forma de a marginalizar.

Assim, nem a marginalização nem a banalização da morte permitem colocá-la a um nível precisamente humano. Ao contrário, a consciência da morte —-melhor, de que se é mortal —é o momento determinante da maturidade. Aí, a pergunta de Leibniz «Porque é que algo existe em vez de nada?» transforma-se nesta outra: Porque é que eu existo em vez de nada?

A resposta dada por cada um a esta pergunta define-lhe a vida. Podemos optar por virar-lhe as costas e viver como se não houvéssemos de morrer. Podemos paralisar-nos na vertigem metafísica como o Fausto de Pessoa. Podemos concentrar-nos no momento presente e vivê-lo humana e seriamente como se fora 0 primeiro, como se fora 0 último, como se fora 0 único 
instante a ser-nos concedido. 0 que não podemos é ignorar que a tremenda e definitiva pergunta se perfila na nossa consciência: Porque é que eu existo em vez de nada? Eu, que agora sou, deixarei de ser daqui a pouco... Que será de mim, quando eu não existir?

A pergunta Como é morrer? ficará eternamente sem resposta... Deixa 0 intelecto na perplexidade não só da mais completa ignorância, mas da absoluta impossibilidade de saber, ao mesmo tempo que acorda no fundo da consciência pessoal 0 eco de nova interrogação ainda mais inquietante: Como morrer? É graças a ela que a Morte pode tornar-se Mestra, verdadeiramente a única Mestra da nossa vida. Pensar na morte é mergulhar no abismo do impensável assim como considerá-la existencialmente, deixar-se tocar pela revelação da morte, é humanizar-se... Por isso escreve Marie de Hennezel (2002:12):

A morte, essa que todos havemos de viver um dia, a que fere os nossos próximos ou os nossos amigos, talvez seja o que nos leva a não nos contentarmos em viver à superficie das coisas e dos seres, o que nos move a penetrar na sua intimidade e na sua profundeza.

É a consciência da morte, isto é, o saber-se cada um detentor de um tempo limitado de existência, que confere 0 carácter verdadeiramente dramático às três perguntas de Kant: Que posso saber? Que devo fazer? Que posso esperar? Cada circunstância (cada situação) da vida, no seu contínuo presente, actualiza estas questões e obriga a uma escolha perante 0 sentido das suas eventuais respostas. Assim como a angústia da morte revela 0 meu ser singular, único e irrepetível, assim também a sua contínua e ameaçadora proximidade nos segreda: este momento que agora vives é único, só 0 vives uma vez. Por isso não há reflexão sobre os valores sem ligação com a morte nem reflexão sobre a morte sem implicações determinantes no domínio axiológico. Em cada circunstância (em cada situação) da vida, no seu contínuo presente, escolho aceitar ou recusar estas questões e 0 sentido das suas eventuais 
respostas. Escolho sempre, ainda que não tenha consciência disso. Posso escolher dedicar-me à filosofia ou à jardinagem. Posso escolher trabalhar ou permanecer ociosa. Posso escolher entre a fé e 0 ateísmo... Mas sempre, em cada escolha, escolho entre estar viva e morrer, entre 0 absurdo e a esperanç̧a, entre 0 ser e 0 nada. Sempre escolho: ou 0 ser porque é e vale, ou 0 nada porque 0 ser me é indiferente e vale para mim tanto como 0 nada. Assim, quer a olhe de frente, quer me esconda dela, a morte está sempre presente aquém da mesma morte, pois, sabendo-0 ou não, ponho em prática uma axiologia: valorizo $a$ e nego $b$. Mais: pela minha escolha efectivada na acção, $a$ chega a ser, enquanto $b$ se desvanece no nada. E por obra dessa escolha, eu própria chego a ser ou desapareço. Nada é neutro. A minha acção $\longrightarrow$ minha escolha efectivada —raz consigo uma axiologia e uma ética. E também uma ontologia e uma antropologia.

Por isso a morte —enquanto enigma e enquanto condição existencial - põe em causa ou conduz a uma reavaliação da escala de valores que se afirma e que se concretiza na acção. É que 0 escândalo da morte é 0 escândalo da morte dos valores e do sentido.

\section{Educar para a morte versus educar para a vida}

A antropologia cultural tem feito notar que a presença do homem pode documentar-se historicamente pela existência de túmulos e ritos funerários. Anselmo Borges afirma mesmo que as culturas são tentativas de encontrar sentido para o problema da morte. E Marie de Hennezel (2002: 12) pergunta: «Sem este problema [a morte] teríamos nós desenvolvido tantas filosofias, tantas respostas metafísicas, tantos mitos?» Em sentido semelhante, Octavi Fullat (1982) interroga-se em Las Finalidades Educativas en tiempo de crisi: «Se é tão corrente morrer, porque não ter isto presente ao educar?» Será que os próprios educadores passam dormentes entre a marginalização da 
morte e a sua banalização? E se eles próprios estão adormecidos perante este mistério, como podem educar uma criança ou um jovem em cuja vida a morte irrompeu como um terramoto? Até para enterrar um peixinho é preciso coragem e dignidade... quanto mais para enfrentar a doença terminal ou a morte repentina de um vizinho, de um colega de turma, dos avós, de um dos pais ou de um irmão... ou de si mesmo...

E todavia, o professor está continuamente a falar de morte e de vida. Fala de civilizações que desapareceram para sempre, de ideias que rapidamente obsolesceram, de autores que deixaram uma obra incompleta. Falam das condições de subsistência, de cuidados a ter com uma saúde e um ambiente cada vez menos promotor de vida...

A morte, chamada ou não a intervir, tem lugar em todas as salas de aula. Senta-se junto de cada educador. A este, a opção de ignorar a intrusa ou de mostrar o lobo que inexoravelmente devora tanto avozinhas como capuchinhos vermelhos e 0 próprio caçador. Mas, prévia a esta opção pedagógica, a decisão do educador enquanto pessoa: para mim, qual a realidade dominante: a vida ou a morte? 0 que vale? 0 ser ou o nada?

Considerar a vida ou a morte como a realidade última de cada pessoa corresponde, em nossa opinião, a dois modos opostos de compreender a pessoa e a sua educação; corresponde a dois modos opostos de encarar a escala axiológica. Por isso, educar é sempre educar para a vida ou educar para a morte, encarando-se, portanto, uma ou outra como valor culminante.

\subsection{Que significa educar para a morte?}

Educar para a morte é, em primeiro lugar, encarar a realidade inevitável da finitude da vida humana. Não se trata apenas de comprovar a sua existência pelo conhecimento da morte do outro, nem sequer apenas de sentir como a morte de quem amamos toca de morte 0 mundo e a nossa visão dele, mas de olhar de frente a morte (o meu ser moriturus) e o medo do nada que ela envolve. 
É este 0 objectivo de Coménio no XIV capítulo da PampaediaSAí fala da escola da morte e considera a arte de morrer bem «digna da meditação e da contemplação de todo 0 homem piedoso», qualifica-a de «salutar»e aponta quanto a esta matéria (para além da obra de Nathan Chytraeus Viático da última viagem, publicado em Herborn em 1608), os mesmos princípios, devidamente adaptados, que propusera para a Escola da Velhice, no capítulo anterior. Tal como em toda a Pampaedia, também aqui Coménio centra a sua exposição no que devem ser as atitudes do sujeito educando - especialmente os velhos, mas afinal todos os homens - preocupando-se com apontar-lhes urna meta para 0 seu esforço de auto-educação em face da inevitabilidade da morte. Coménio escreve:

«Sem dúvida, de todas as coisas terríveis, a mais terrível é a morte [...]. Portanto, a ninguém devem faltar boas advertências sobre como deva comportar-se, com prudência, nesta circunstancia em que, como entre Cila e Caríbdis, não se pode fugir ao medo de ser ou despedaçado, ou engolido: 0 que, pelo que diz respeito ao corpo, acontece a todos, e, pelo que diz respeito à alma, a muitos.» (Coménio, 1971: 334).

Neste contexto, como também refere Coménio, tem o seu lugar a definição platónica de filosofia como «treino de morrer e de estar morto», entendido este treino no sentido de morrer bem:

«Com efeito, a melhor parte da filosofia é, sem dúvida, aprender a morrer, isto é, a morrer bem. Na verdade, para morrer não é necessária nenhuma arte, pois é uma coisa espontânea; mas morrer bem é a arte das artes.» (Coménio, 1971: 337).

(2) A Pampaedia é a terceira parte do monumental projecto, a Consultatio Catholica, na qual João Amos Coménio se propõe demonstrar «a necessidade, a possibilidade e a facilidade de os homens serem educados» e de 0 serem todos, em todas as coisas, totalmente, sempre. Para isso, apresenta a prática segundo a qual todos, gradualmente e em conformidade com a sua idade, devem frequentar, sete escolas - que afinal são oito - a última das quais é a escola da morte. (Cf. COMENIO, João Amos (1971), Pampaedia (Educação Universal), Introdução, tradução e notas por Joaquim Ferreira Gomes, Coimbra: Faculdade de Letras da Universidade de Coimbra). 
Coménio está a referir-se à conhecida passagem do Fédon de Platão em que Sócrates dirige aos discípulos que 0 acompanham estas palavras:

0 comum das pessoas está, provavelmente longe de presumir qual 0 verdadeiro alvo da filosofia, para aqueles que porventura 0 atingem, e ignora que a isto se resume: um treino de morrer e de estar morto. (Fédon, 64a)

Afastemo-nos por momentos de Coménio para nos determos um pouco sobre esta ideia e obra. As palavras de Sócrates ao longo do colóquio que estabelece com os discípulos soam-nos desencarnadas. Sócrates fala da morte como se não estivesse a ponto de morrer, como se a morte fora um tema de conversa tão exterior e abstracto como a linguagem ou as leis de outra cidade. Um laivo de ironia chega mesmo a assomar quando, recebendo a taça com veneno das mãos do carcereiro, lhe pergunta se poderá fazer uma libação... Ainda que tudo esteja para ele perdido, Sócrates olha para fora de si, para 0 que pode ainda fazer como educador e mestre, parecendo dar razão a Wittgenstein: a morte não é um acontecimento da vida, a morte não se pode experimentar. Na verdade, é pelas lágrimas dos discípulos que a realidade da morte do mestre se faz presente. Quanto a este, é por estar vivo que pode perspectivar um futuro, uma vida para além desse instante. É por estar vivo que pode escolher beber de um trago a taça de cicuta. Até aí, até que 0 veneno the tome conta do corpo, Sócrates assume 0 seu estar vivo e 0 seu poder de ser mestre. E assim como anteriormente, perante 0 tribunal, escolhera não mendigar 0 perdão, escolhe agora apresentar-se diante dos discípulos como aquele que, tendo levado a vida filosofando, recebe a morte como a sua natural consequência. No momento derradeiro, que Sócrates sabe ser precisamente 0 derradeiro, escolhe viver 0 último presente diante dos discípulos como exemplo de vida digno, referindo a necessidade de oferecer em sacrifício um galo a Apolo, precisamente um símbolo de vida a um deus de vida. Isto é, educando para a morte, é mestre de vida enquanto há vida. Comentando o mesmo episódio, Montaigne diria 
que «quem aprendeu a morrer desaprendeu de servir. 0 saber morrer libertamos de toda a sujeição e constrangimento.»

Também numa obra recente, As Terças com Morrie, Mitch Albom relata a atitude perante a doença terminal de Morris Schwartz, o seu antigo professor, que sofria de esclerose lateral amiotrófica. À semelhança de Sócrates, Morris Schwartz, faz do seu percurso para a morte uma ocasião para a aprendizagem dos outros:

«0 meu velho professor tinha tomado uma decisão profunda, uma decisão que começara a tomar forma no dia em que saíra do consultório do médico com uma espada pendurada sobre a sua cabeça. Vou definhar e desaparecer; ou faço o melhor do tempo que me resta?, perguntava-se a si mesmo.

Ele não definharia. Não teria vergonha de morrer.

Em vez disso, tornaria a morte no seu último projecto, o ponto fulcral dos seus dias. [...]

Morrie iria atravessar essa ponte final entre a vida e a morte, e narrar a viagem.» (Albom, 2003: 18-19)

Como atras fizemos notar, a morte surge no contexto da vida. Falo da morte, penso a morte porque vivo... Experimento a morte dos que me são queridos como circunstância minha. Posso antecipar a ideia de que sou mortal. Porém, não poderei nunca viver ou antecipar a consciência da minha morte, mesmo que, como Sócrates, me tenham marcado 0 momento da sua chegada. Assim, a filosofia como treino para morrer e estar morto parece-nos algo contraditório, como conclui Maria Filomena Molder (2003: 20) comentando Paul Valéry:

Se a filosofia é uma forma de preparação para a morte e se 0 filósofo for um pretenso agonizante que, como Lázaro, foi pela mão do Salvador, chamado de novo à vida, então, se assim for, 0 pensador não pode falar de morte, só poderá falar de vida. 
Resta saber se, como ela pergunta adiante, «poderão os filósofos aceitar que alguém os salva, que alguém os salvou» ou se é 0 seu próprio olhar estranhando-se vivos a voz salvadora que os chama à vida. A estranheza de se saber vivo, de se saber vivo desde antes de 0 ter estranhado, de não poder saber de si senão estando vivo, está no momento inaugural da filosofia lado a lado com essa certeza nunca acreditada de morrer. Assim, a definição da filosofia como treino para morrer e estar morto parecemos compreensível apenas se se entende 0 momento da morte como 0 último momento de vida, 0 indefinível instante de passagem em que a vida inteira é assumida, aceite e transformada, à maneira do que dizia 0 poeta: «Saiba morrer 0 que viver não soube». E, todavia, enquanto tal momento não chega, posso negar à vida 0 seu valor. Posso negar a vida. Posso morrer cada instante como se não houvesse de viver. E por isso preciso de olhar de frente a realidade: 0 meu tempo é limitado. A morte do outro, do outro que me é próximo, do outro que eu amo, ou apenas do outro que se me faz próximo porque vai morrer é a grande mestra desse único e definitivo ensinamento: «não convivemos impunemente com alguém acariciado pela morte e que, sabendo-0, vive tudo 0 que the acontece como um dom» (Hennezel, 2002: 20).

A frase de Coménio que antes citámos («para morrer não é necessária nenhuma arte, pois é uma coisa espontânea; mas morrer bem é a arte das artes») recorda-nos a distinção de Heidegger entre 0 acabar e 0 morrer. Com efeito, se os limites da vida são evidentes em situações de dor, velhice, solidão, abandono, hostilidade,... estes só se tornam experiência e educação para a morte se encarados e conscientemente vividos como ocasião para penetrar na realidade última a que Coménio chama a eternidade e Morris Schwartz resume em amor, abandono interior, quietude.

Este é um longo caminho, quer para um doente terminal, quer para uma pessoa fisicamente saudável e qualquer que seja a sua idade, porém de modo particular para os velhos. Assim, Coménio propõe três passos sucessivos a que chama as classes da escola da velhice: 
- «a daqueles que examinam as suas tarefas (as já realizadas e as a realizar ainda)»;

- «a daqueles que se apressam a fazer o que falta ainda fazer»;

- «a dos decrépitos que nada mais fazem senão esperar a morte».

Vieira (1959: 190) vai ainda mais longe no final do seu Sermão da Sexagésima, propondo a todos os homens uma auto-educação em que a vida e a morte se tocam. A morte é 0 momento sempre imprevisível em que se joga o tudo ou nada da vida e, ao mesmo tempo, a sua consideração permite transformar a vida que entretanto nos seja concedida:

«Homens imortais, homens mortais, se todos os dias podemos morrer, se cada dia nos imos chegando mais à morte, e ela a nós, não se acabe com este dia [quarta-feira de cinzas] a memória da morte. Resolução uma vez, que sem resolução nada se faz. E para que esta resolução dure, e não seja como outras, tomemos cada dia uma hora em que cuidemos bem naquela hora. De vinte e quatro horas que tem 0 dia, porque se não dará uma hora à triste alma? [...] Tomar uma hora cada dia, em que só por só com Deus e connosco, cuidemos na nossa morte e na nossa vida. E porque espero da vossa piedade e do vosso juízo, que aceitareis este bom conselho, quero acabar, deixando-vos quatro pontos de consideração para os quatro quartos dessa hora: Primeiro, quanto vivo? Segundo, como vivo? Terceiro, quanto posso viver? Quarto, como é bom que viva? Torno a dizer para que vos fique na memória: Quanto tenho vivido? Como vivi? Quanto posso viver? Como é bem que viva? Memento homol»

Olhando a última das classes definidas por Coménio, assim como este programa de meditação de Vieira, é inevitável 0 encontro com a proposta de diferentes místicas: 0 desprendimento e a "pobreza de coração», bem expressa na frase de Manuel Antunes (1973: 115-6): «ter, sobra». Esperar 
a morte e morrer, depois de cumprido o que devia e podia ser feito, é abandonar deliberadamente tudo 0 que não serve 0 essencial, na fidelidade a si mesmo. Por isso, a morte envolve 0 paradoxo da solidão e da comunhão. Por um lado, ela é 0 acto mais definitivamente solitário: aprender a morrer é aprender a estar só. Só, diante de si mesmo. So, diante dos outros. So, diante do Ser. Por outro, é o ponto de comunhão universal em que o já-nao-ser toca 0 Ser e lhe dá condições de enriquecer-se e superar-se: aprender a despedir-se (começar a morrer) é aprender a viver.

\subsection{Que significa educar para a vida?}

A expressão «educação para a vida» aponta tradicionalmente para a capacidade de ultrapassar os obstáculos da existência, em termos individuais e a adaptação às estruturas em termos sociais.

A etimologia ensina que «Pedagogia é [...] uma outra forma de dizer 'Vida'.» Por detrás de todo 0 vocabulário pedagógico, brilha «uma galáxia semântica estruturada em redor do sistema biológico da vida» que envolve «a criaçãa de condições para a sua gestação, através da existência de uma atmosfera propícia»; 0 nascimento com tudo o que este implica de plenitude e de ruptura» e a garantia de manutenção da mesma vida, pela alimentaçãa, e da sua qualidade pelas condições de segurança, comunicação e mobilidade (Gomes, 2003: 36-7). Também Ribeiro Dias tem feito notar que educar é, em primeiro lugar, gerar e criar condições para que a vida se desenvolva —ida de todos e cada um dos homens e em todas as suas dimensões (Dias, 2000).

$\mathrm{Na}$ esteira de Rousseau, a Educação Nova identifica educação para a vida com a educação segundo a natureza, isto é, acentua a dimensão prática da aprendizagem e 0 seu fundamento bio-psico-social, ao mesmo tempo que, em termos de currículo, põe a tónica na educação do corpo, trabalhos manuais, actividades de ar livre, etc., vindo a gerar alguma confusão entre diferentes acepções da palavra natureza. 
Por outro lado, a aplicação ao terreno educativo das teses rogerianas, a par das noções de educação de adultos e de educação permanente, fezmos cair na conta que educar é criar condições para urna vida cada vez melhor, isto é, para que todos e cada um reconheçam as suas necessidades e aspirações e se tornem capazes de encontrar meios de as satisfazer. Neste percurso, é fundamental, como Paulo Freire sublinhou pela obra escrita e pela prática de educador, o lugar para a palavra. Educar é criar condições para 0 emergir da palavra do educando-educador, expressão da sua cultura — da sua hermenéutica do mundo — e ela própria geradora de uma cultura renovada na comunicação de ambos.

Dentro do espírito desta evolução e aprendendo com todos os que se debruçam sobre a educação de valores, anotemos que educar é criar condições para a escolha pessoal, a qual implica sempre a emergência de um critério de escolha, gradualmente consciente e assumido, de acordo com a idade do educando. Ora, encontrar um critério de escolha, isto é, encontrar em si mesmo e para si mesmo a lei do e para 0 seu próprio agir, é mais que a liberdade. A liberdade pode entender-se como capacidade de escolha ou como capacidade de escolha do bem. Em ambos os casos, implica uma intencionalidade que, por um lado, é exterior à opção, mas, por outro, é a sua justificação. Esta intencionalidade postula a sua própria continuidade, pelo que aponta para uma capacidade existencial de continuar a escolher, ou seja, para 0 não fechamento da pessoa à autotranscendência, o desenvolvimento do que a define como eu e não apenas como individuo. A pessoa é Sentido/Projecto, categoria que, constituindo-se como critério de escolha, conduz ao desenvolvimento da autonomia. 0 conceito de autonomia aponta, pois, para uma realidade mais funda que a liberdade: a pessoa humana como telos, já afirmada por Kant, que se constitui como norma de si mesma. A autonomia vem, então, a ser a própria condição de existência da liberdade.

Ora, se a autonomia corresponde a uma lei para 0 agir próprio que a pessoa não cria mas descobre em si mesma e the permite 0 desenvolvimento do melhor 
de si mesma, então a autonomia tem a sua origem no núcleo da identidade pessoal que, procurando sintetizar 0 ensinamento de diferentes tradições sapienciais, designamos espiritualidade e definimos como a percepção situada do fundo onto-teleológico do ser humano, experimentada e tornada consciente, que se traduz dinamicamente na auto-compreensão e auto-realização, na relação com os outros e com o mundo e na abertura ao Transcendente.

Educar para a vida é, num primeiro nível, criar condições para a sobrevivência em termos biológicos ou em termos sociais. Mas vem a ser, pela própria exigência da vida humana, criar condições para a descoberta do núcleo da identidade pessoal e para a relação com os outros, com 0 mundo, com 0 Ser — isto é, educar para a espiritualidade. Educar para a vida é reconhecer na própria vida pessoal um processo gradual e nunca terminado de crescimento e comprometer-se com esse mesmo crescimento. Ora este caminho que começa por fazer-se pela mão de outro é, em si mesmo, um caminho que tem de fazer-se com os próprios pés, isto é, visa a capacidade de estar sozinho (mas não isolado) perante as escolhas e 0 sentido da própria vida.

Aí onde tudo o que nos ocupa cessa — víamos há pouco —é o acto mais definitivamente solitário: sou eu perante 0 nada. Mas uma decisão, uma escolha radical experimenta-se também como um acto solitário: antes de efectivar-se na acção, a escolha é fruto da deliberação da consciência pessoal. Assim, aprender a viver é ir aprendendo a morrer -a deixar morrer para si, em cada escolha feita, tudo o que é abandonado... Aprender a morrer é aprender a viver —é abandonar deliberadamente tudo o que não serve 0 essencial. É ser e querer ser mais.

0 que nos surpreende —em Sócrates, em Jesus... como em Morris Schwartz ou noutros sábios ou santos que só os amigos conheceram -é a sua capacidade de se manterem educadores até ao fim. A vida —os últimos dias ou meses da vida configuram na verdade a vida inteira — foi para eles aprender a morrer e este mesmo processo é a afirmação da vida como valor culminante. 
Embora a atitude de cada um deles seja diferente face ao sofrimento e à morte — Sócrates morre com a serenidade do filósofo, como um deus, ao passo que Jesus morre gritando, como um homem que assume até ao fim 0 horror da aniquilação da sua humanidade — ambos nos fazem recordar V. Frankl (1993,2: 91) no seu testemunho sobre a vida nos campos de concentração nazis:

era preciso aprendermos por nós mesmos e, além disso, era preciso mostrarmos àqueles que eram tomados de desespero que o importante não era o que nós esperávamos da vida, mas o que a vida esperava de nos.

A vida assume a dimensão de totalidade e de ultimidade exigidas pela categoria do sentido, tal como ela é entendida na filosofia ou nos estudos linguísticos. Assim, à semelhança de Ortega que sublinhava a responsabilidade do sujeito face à sua circunstância, diremos: talvez não seja responsável pelo que me acontece e pelo que acontece à minha volta, mas sou sempre responsável pelo que faço com o que me acontece, ou com o que fizeram de mim. A circunstância (inclusive a circunstância interior como, por exemplo, o estado do corpo ou as emoções) condiciona-me, mas, acima de tudo, interpela-me. E, se não respondo à sua interpelação, perco a oportunidade de sentido na transitoriedade da vida. Dissolvo-me... Opto pelo não ser. Morro-me nesse instante e morro nele o meu futuro possível.

\section{A vida como valor culminante e os momentos da sua praxis axiológica}

A análise que fizemos no ponto anterior e que poderia ser enriquecida pela consideração pormenorizada das mais diversas tradições e culturas, bem como a experiência de contacto com situações de sofrimento, velhice, solidão, abandono, hostilidade,... e a análise de algumas atitudes comuns no nosso tempo (por exemplo, grande número de suicídios, especialmente 
entre os jovens, defesa e pedido expresso de eutanásia, baixa taxa de natalidade, a par de práticas de aborto ou procriação selectiva) obrigam-nos a reconhecer que a afirmação da vida como bem ou valor não é de modo nenhum universal.

Tomemos, como exemplo dos que negam valor à vida 0 suicida. 0 seu gesto não tem nem pretende ter um alcance universal, mas é inegável que, para 0 suicida, a morte é preferível à sua vida, a vida vale menos que 0 não ser. Inversamente, a plena aceitação da vida tem, para aquele que a assume, um efeito libertador. Considerar a vida como o valor (bem) culminante corresponde a encarar a existência como um dom que nos é proposto para que 0 valorizemos e que só assim pode chegar a ser: a vida é mera possibilidade cuja actualização nos está encomendada, constituindo a ocasião de nos enriquecermos, a nós e ao mundo (Quintana Cabanas, 1998: 267).

A escolha da morte é a morte dos valores e do sentido, assim como a escolha da vida é a condição necessária à emergência de novos valores que conferem densidade e sentido à existência pessoal. Assim, a vida como escolha aparece-nos penetrada pelo que Quintana Cabanas designa vontade de valor, é ela própria valor e valor culminante.

Manuel Patrício (1993: 61-2) sublinha que a missão do conhecimento axiológico é a sua realização e vivência integral. Define 0 mesmo autor quatro momentos estruturais da praxis axiológica:

- Percepção: capacidade de identificar um valor;

- Fruição: experiência gozosa do valor;

- Criação: «de um objecto ou realização de um acto que incorpora 0 valor»;

- Promoção ou difusão: acto de «induzir no outro, ou nos outros, a experiência do valor em algum ou alguns dos seus momentos».

Apliquemo-los agora ao que designámos como educação para o valor culminante da vida. 
0 exemplo de Sócrates atrás referido a propósito da teoria de Coménio sobre a educação para a morte, mostra como é necessária e determinante a figura do educador para a emergência e 0 desenvolvimento nos educandos dos valores culminantes. Definimos assim o momento axiológico da promoção 441 como a atitude — necessária em todo 0 educador — de olhar a realidade da vida na sua estreita relação com a morte (morte do outro e morte própria) e a essa luz suscitar nos educandos a capacidade de percepção, fruição e criação da vida como valor.

Mitch Albom (2003: 65) relata assim uma das suas conversas com Morrie, 0 seu antigo professor:

«- Mitch, [...] a cultura não nos encoraja a pensarmos nestas coisas até estarmos a morrer. Estamos tão embrulhados em coisas egoístas, a carreira, a família, ter dinheiro suficiente, pagar o empréstimo, comprar um carro novo, arranjar o radiador quando se avaria - estamos envolvidos em triliões de pequenos actos apenas para continuar a viver. Por isso não adquirimos o hábito de nos afastarmos e olharmos para as nossas vidas, e dizer, «É só isto? Isto é tudo o que eu quero? Falta alguma coisa?» [...] É preciso que alguém nos conduza nessa direcção. Não acontece automaticamente.»

Este acto inaugural e o hábito que se lhe segue de nos afastarmos, olharmos para a nossa vida e nos interrogarmos sobre o seu conteúdo, correspondem, em nosso entender, ao momento axiológico da Percepção. Vem a ser 0 olhar a vida na sua dinamicidade, dramaticidade e finitude em confronto com um horizonte de totalidade e inteligibilidade, isto é, em confronto com 0 seu sentido. É o momento de maturidade em que se sente e se sabe que não se está no mundo por um acaso, mas para alguma coisa ou, como escreveu Fernando Pessoa, «a consciência (que em mim é quotidiana) da terrível importância da Vida.»(1986: 175). 
0 momento seguinte (Fruição) vai para além da compreensão. 0 estar no mundo para alguma coisa é sentido na intimidade do eu perante 0 seu tempo, a sua circunstância, aqueles que se amam, como gerador de diferença, de riqueza, de ser. A compreensão deste momento é indissociável da reflexão de Lévinas sobre a Ética como filosofia primeira e da sua afirmação da primazia do outro. É 0 encontro com 0 outro, irredutível à conceptualização e à mesmidade que possibilita 0 abrir-se à experiência gozosa da vida própria, e nela da comunhão, como valiosa e sagrada. É esta atitude que permite integrar os momentos dolorosos, em lugar da revolta e do desespero.

Como anotámos anteriormente, os valores implicam no sujeito uma síntese dinâmica de adesão afectiva, juízo racional e acção coerente e é apenas nesta última — na escolha, como repetidamente afirmámos — que 0 valor se realiza. Assim também, a percepção e fruição ficam incompletas e frustradas se não se traduzirem em actos de reconhecimento e respeito do outro e no esforço de crescimento pessoal, isto é, se não conduzirem ao momento axiológico da Criação: «alcançar a plenitude da vida na brevidade do tempo».

0 momento axiológico da Criação é um compromisso com a vida: querer crescer como pessoa, no que mais profundamente define 0 eu, e querê-lo com todas as forças. Podemos ainda reconhecer nele três dimensões: correr riscos, gerir o tempo próprio e lidar com a angústia (Fagot-Largeault, 2001: 1682)

Em resumo, poderíamos traduzir, do ponto de vista do educando, os momentos da praxis axiológica quanto à vida como valor culminante em três verbos: ver, sentir, querer (a que acrescentaríamos, do ponto de vista do educador, quanto ao momento da promoçãa, amar). Este arco axiológico — da percepção à fruição e desta à criação —não pode realizar-se sem a afirmação da perfectibilidade e da Esperança que não resultam da evidência dos factos nem da dedução lógica, mas constituem um postulado, como veremos a seguir. 


\section{Conclusão: fundamentos de uma educação para a vida}

0 problema dos valores culminantes conduziu-nos à necessidade de uma Educação para a Morte / Educação para a Vida, susceptível de ser analisada nas várias acepções da Teoria da Educação que apontámos no ponto 1, seguindo Carrasco e Dujo. Muito embora não tenhamos analisado as múltiplas formas como as diferentes tradições culturais encaram «0 mais terrível dos males», no ponto 4.1, partindo de Coménio, Vieira, Platão e M. Albom, considerámos 0 mistério da morte como situação que impele 0 ser humano à re-avaliação da estrutura simbólica com a qual se tomam as decisões educacionais (cf. TE 1). No ponto 4.2. vimos como a noção de educação para a vida, tradicionalmente mais enquadrada no contexto pedagógico, permite, em primeiro lugar, sistematizar a interpretação de situações pedagógicas específicas (cf. TE 2) e, depois, permite problematização das conclusões do ponto anterior e, com a ajuda da filosofia, abre caminho para a busca de fundamentos para uma pedagogia do discernimento e, assim, de uma TE 3.

Neste percurso, o mistério da vida e a situação-limite da morte revelaram-se-nos como facto indesmentível que, todavia, suscita atitudes opostas: uns afirmam a primazia da vida como imperativo ético; outros chamam-lhe «vale de lágrimas» e anseiam pela morte como por uma libertação; outros ainda situam-se perante uma e outra igualando-as no mesmo desvalor ou, o que é o mesmo, olham-nas suspendendo o juízo a seu respeito. A divergência de posições e critérios que constatamos parece fruto mais de uma disposição da vontade que de um juízo sobre factos objectivos. Com efeito, a resposta afirmativa à pergunta «a vida vale?» resulta da vontade de acreditar no valor (na bondade) da mesma vida e, portanto, de responder às interpelações desta com uma atitude também ela de bondade e valorização das circunstâncias. Ao invés, a resposta negativa conduz à desresponsabilização do sujeito face a um eventual avanço do que ele próprio avalia como mal ou cultura 
Generalizando esta nossa afirmação, diríamos que 0 suporte de urna Teoria da Educação enquanto organização de conceitos educacionais construída mediante a aplicação de critérios e regras da epistemología (TE 3) é indissociável de um conjunto de crenças fundacionais, isto é, da explicitação da representação intelectual com que os profissionais da educação interpretam situações pedagógicas específicas (TE 2) e da estrutura simbólica com a qual os educadores (profissionais ou não, conscientes dela ou não) tomam decisões educacionais (TE 1). Este nosso modo de encarar 0 problema vê-se confirmado pela análise de Hubert Hannoun (1995: 223-232) — que, por sua vez, se baseia em Aristóteles e Goblot — segundo 0 qual podemos fundamentar os meios da nossa acção, os métodos (0 como), mas não os fins (o porquêe). Assim, segundo Hannoun, as finalidad es da educação são 0 resultado menos da reflexão racional que do interesse, do imaginário ou de um acto de fé individual ou colectivo, actos que podemos chamar meta-racionais. 0 trabalho do educador exige, portanto, por um lado, a reflexão racional sobre os meios e, por outro, a sua crença e a aposta no futuro.

Tal como este autor, consideramos que não é a existência da educação que demonstra a perfectibilidade dos indivíduos, mas é porque se aceita, se crê, na perfectibilidade, na progressiva concretização do futuro do educando, que a tarefa educativa se realiza. $\mathrm{Na}$ pedagogia, esse sequitur agere, 0 ser segue 0 agir. Assim, a educação pressupõe uma aposta no futuro (na Vida) que a razão não justifica, mas que 0 acto educativo torna inevitável e se traduz na afirmação da perfectibilidade e na esperança. Quanto à meta desta perfectibilidade $\longrightarrow$ que, no quadro da nossa exposição chamamos «valores culminantes» —entende 0 mesmo autor que não poderá ser 0 resultado de uma escolha entre várias finalidades possíveis, mas da sua constatação tanto no conjunto da humanidade como em cada indivíduo. Procurámos mostrar como 0 enigma da morte e a inerente afirmação da vida se incluem nesse «universal concreto». 
Por outro lado, so podemos julgar 0 valor de algum bem relativamente a um valor ou um bem que não julgamos, tal como so podemos avaliar 0 sentido de alguma coisa relativamente a uma totalidade que a envolve. Assim, o bem para que tende a educação, o bem constatado no íntimo de 445 cada ser humano é 0 seu ser precisamente humano, 0 seu ser pessoa. Sem a pessoa os valores não existem. Em consequência, diremos que a pessoa é sagrada e só ela é sagrada. É pois a pessoa que confere valor sagrado àquilo que toca, àquilo que seja meio para a sua existência, à própria função do educador e da educação. É em função da pessoa e do seu ser sagrado que se originam as várias ordens de valores e a sua hierarquia. A Pessoa é a justificação última da educação de valores porque é a justificação única da educação. Mas também perante a realidade indesmentível da morte, só 0 crescimento (a educação de si mesmo) permanece.

Assim, a pergunta pelo sentido do mundo, da vida e do educar, dilui-se no silêncio de uma íntima descoberta: nem o princípio e 0 fim de uma existência se resumem a nascer e morrer, nem na morte morre 0 sentido que a pessoa quis dar à vida. Mas, pela grandeza do que toca, este é um silêncio que clama pela acção de cada educador e que, do núcleo de cada ser humano, intima à dedicação esforçada da investigação teórica. 
A lbom, M itch (2003), As Terças com Morrie, Lisboa: Público.

Borges, Anselmo (1988), «A necessidade de morrer», Associação de Médicos Católicos Portugueses, Da Vida à Morte, Coimbra, pp. 273-303.

Borges, Anselmo (1999), «M orte, Pessoa, Transcendência», AAW, Da natureza ao sagrado. Homenagem a Francisco Vieira Jordão, Porto: Fundação Eng. António de A Imeida, pp. 67-100.

Carrasco, Joaquim Garcia \& Dujo, Ángel Garcia (1996), Teoria de la Educación; 1 - Educación y Acción Pedagógica, Salamanca: Ediciones Universidade.

Coménio, João Amos (1971), Pampaedia (Educação Universal'), Introdução, tradução e notas por Joaquim Ferreira Gomes, Coimbra: Faculdade de Letras da Universidade de Coimbra.

Dias, J. Ribeiro (2000), A Realização do Ser Humano, Lisboa: Didáctica Editora.

Fagot-Largeault, «Vie et Mort», Canto-Sperber, M. (Dir.) (? 2001), Dictionnaire d'éthique et de philosophie morale I, Paris: PUF, pp. 1677-1684.

Freire, Paulo (1997), Pedagogia da Autonomia: Saberes necessários à prática educativa, s. Paulo, Paz e Terra.

Fullat, O ctavi (1982), Las finalidades educativas en tiempo de crisis, Barcelona: Hogar del Libro.

Fullat, Octavi (1991), «Estatuto Epistemológico de la Filosofia de la Educación», AA. W, Filosofia de la Educación Hoy. I - Conceptos, autores, temas, Madrid: Dykinson.

Gomes, A. (2003), A Aula, Porto: Porto Editora.

Hannoun, Hubert (1995), Comprendre l'Éducation. Introduction à la philosophie de l'éducation, Paris: Nathan.

Hennezel, M .(2002), Diálogo com a morte, Ed. Notícias, Lisboa, 5aed..

Patrício, M anuel (1993), Lições de axiologia educacional, Lisboa: Universidade A berta.

Pessoa, Fernando (1986), Obra Poética e em Prosa, Introdução, Organização, Biobliografia e N otas de A ntónio Quadros e D alila Pereira da Costa, Porto, Lello \& Irmão.

Pessoa, Fernando (1988), Fausto. Trajédia subjectiva (Fragmentos), Estabelecimento do texto, ordenação, notas à edição e notas de Teresa Sobral Cunha. Prefácio de Eduardo Lourenço, Lisboa: Editorial Presença.

Quintana Cabanas, José Maria (1998), Pedagogia Axiológica. La Educación ante los Valores, Madrid: Dykinson.

Réboul, Olivier (1992), Les valeurs de l'éducation, Paris: PUF.

Savater, F. (1982), Invitación a la Etica, Barcelona: A nagrama.

Vieira, Pe. Antonio (1959), «Sermão de Quarta-Feira de Cinzas pregado em Roma na Igreja de Santo A ntónio dos Portugueses em 1672», Sermões, Porto: Lello \& Irmão Editores, vol. II 